\title{
DETERMINATION OF THE FEASIBILITY OF TOURISM VILLAGES IN WEST MANGGARAI REGENCY
}

\author{
Roseven Rudiyanto $^{(1) *}$, Anggi Januar( ${ }^{(2)}$ \\ (1) Program Studi DIII Ekowisata, Politeknik eLBajo Commodus \\ (2)Swisscontact Sustour \\ roseven@poltekelbajo.ac.id, anggi.januar@swisscontact.org \\ Submitted: 31 January $2021 \quad$ Revised: 20 March 2021 \\ Accepted : 1 April 2021
}

\begin{abstract}
The purpose of this study is to assess the readiness of the two villages proposed by the Regional Government of West Manggarai Regency (Wae Sano and Wae Lolos Villages) as a tourism village using an instrument compiled through focus group discussions with stakeholders in the field of tourism village development. Therefore, the local government intend to promoting cultural attraction as an effort to reduce negative impacts at Labuan Bajo and at the same time equalize the positive impacts of tourism. The approach of quantitative descriptive method was used on data obtained through focus group discussions and observations to test the readiness of a village to become a tourist village. The data analysis technique uses the interval interpretation technique, in which there are three interval categories. The results of this study indicate that there are six variables assessed in the tourism village assessment instrument, namely 1) attractions (nature and culture), 2) accessibility, 3) amenities (public facilities and tourism support), 4) institutions and society, 5) strategy. marketing, and 6) industry. Based on the results of the study, it can be concluded that the Wae Sano villages and Wae Lolos villages can be included in the category "can be recommended to become a tourist village with a note". This is due to records in several aspects, such as amenities, marketing strategies, and industry in the two villages.
\end{abstract}

Keywords: Amenities, Cultural Attractions, Institutional and Community, Tourism Village Determination, West Manggarai

\section{INTRODUCTION}

Tourism is one of the most developed industries. According to the World Travel \& Tourism Council report (2020) contribution of the Travel \& Tourism industry to global GDP is $10.3 \%$. He further explained that the growth of the Travel \& Tourism industry globally is in the third rank (4.8\%), after the information and communication industry $(4.8 \%)$ and financial services $(3.7 \%)$. Global industrial development also has an impact on the Indonesian economy as a whole. Based on data from the Badan Pusat Statistik (2020), it is explained that the amount of foreign exchange originating from the tourism sector reached 11.206 billion USD in 2016, an increase of $17 \%$ to 13.139 billion USD in 2017 , and in 2018 there was an increase of $25 \%$ to 16.426 billion USD.

Tefler \& Sharpley (2008) argue that tourism activities themselves can have an impact on the destination, its environment and local communities. The impacts of tourism can be in the form of erosion of local culture, loss of local architecture, to 
changes in livelihood sources (Khandare \& Phophueksanand, 2018). One of the solutions to reduce the impact of tourism is to maximize the role of tourism villages (Leonandri \& Rosmadi, 2018) (Muganda et al, 2013). UNWTO (2020) defines that rural tourism is a type of tourism activity that offers visitors experiences related to natural, agricultural and cultural activities or rural lifestyles (Hidayatullah et al, 2017). On the other hand, the presence of a tourist village can make rural communities benefit from the development of the tourism industry (Amerta, 2017). Sharafieva (2012) explains that increased employment opportunities, income growth, and increased living standards are one of the benefits of tourism in the socioeconomic aspect. However, according to The Indonesian Ministry of Tourism (2019) an instrument must be applied in determining a village to be a tourist village, such as proposing a tourism village determination by community groups to the village government which is approved through deliberation, then the results of the deliberation on the village head's decision are conveyed to the development of tourism villages to the Regional Work Units in charge of tourism affairs, and they carry out verification, due diligence on proposed tourism villages, where villages that fulfill the assessment are determined by a district head decree.

West Manggarai Regency is one of the districts that has benefited from the development of the tourism industry in Indonesia. The Pariwistaa and Culture Office of West Manggarai Regency explained that the local revenue of West Manggarai Regency from the tourism sector in 2017 the contribution of the tourism sector was $19.80 \%$ of the total PAD or Rp. 24,445,107,113. and increased in 2019 by $35.65 \%$ or Rp. $60,572,930,746$ (Tourism and Culture Office of West Menggarai Regency). However, tourism activities in West Manggarai Regency are still centered in Labuan Bajo, which has been designated as a super priority tourism destination. Therefore, by promoting tourism villages West Manggarai Regency government hoped that the benefits of tourism can be felt equally. The problem faced by the local government of West Manggarai Regency is that it does not have an instrument to assess the readiness of a village as a tourist village. Therefore, this study aims for the purpose of this study to assess the readiness of the two villages proposed by the Regional Government of West Manggarai Regency, namely Wae Sano and Wae Lolos Villages as tourism villages.

\section{LITERATURE REVIEW}

\section{Traditional Village as Tourism Industry}

There are several definitions of tourist villages. Regulation of the Minister of Culture and Tourism number KM.18 / HM.001 / MKP / 2011 states that a tourism village is a form of integration between attractions, accommodation and support that is presented in a structure of community life that integrates with the prevailing procedures and traditions. According to Inskeep (Franisal, 2020) a tourist village is a place where a small group of tourists live in or near a traditional village (Gundolf \& Jaouen, 2005), which is usually remote, to learn about village life and the local environment (Komariah et al, 2018). Yoeti (1996) states that a tourist village is a rural area that has several special characteristics to become a tourist destination. These characteristics can be in the form of socioeconomic life, socio-culture, daily customs, building architecture and typical village spatial structures, or unique and interesting economic activities (Hadiwijoyo, 2012). Kulcsar (in Ayazlar and Ayazlar, 2015) explains that activities in tourist villages can be in the form of traditional ceremonies or celebrations, outdoor recreation, and enjoying nature. 


\section{Tourism Village Aspects}

As a destination, a tourism village must have aspects that support tourism activities in it, namely Attractions, Activities, Accessibility, and Accommodation (4A) (Nuryanti, 1993). Akrida and Pujani (2017) create a criteria matrix for tourism villages consisting of aspects of nature/bio-biology, physical environment, amenities/infrastructure, institutions, human resources, attitudes and life order of local communities, and accessibility.

The Ministry of Tourism in the Guidelines for Tourism Villages (2019) explains that a tourist village is considered a geographical area that has criteria such as tourist attraction (DTW), accessibility, amenities, human resources (HR), society, industry, branding, advertising, and selling. Pusparani (2020) explains that the components of tourism village products include tourist attraction (DTW), accessibility, supporting facilities, and supporting organization/institutions.

\section{RESEARCH METHOD}

The approach of this reserch used quantitative method, and according to Wiliams (2007) quantitative methods make research objective by revealing reality based on the data collected. With a quantitative approach, this research examines the readiness of a village to become a tourist village in West Manggarai Regency based on objectively determined aspects.

\section{Research Instruments}

The preparation of a tourism village assessment instrument was carried out through a focus group discussion (FGD) that involved stakeholders in the tourism village sector. The regional government of West Manggarai Regency is represented by the Tourism and Culture Office, the Regional Research and Development Planning Agency, the Community and Village Empowerment Service, the Public Works Service, and the Forest Management Unit Service. The private sector is represented by the West Manggarai Indonesian Tour Guides Association (HPI) and the West Manggarai Indonesian Travel Association (ASITA). In addition, there were several other agencies that attended the FGD process, including Polytechnic eLBajo Commodus from the academic sector, Swiss Contact Sustour as a non-governmental organization, and several community leaders. The FGD was held for six meetings. The determination of assessment aspects and variables is based on a study of the preparation of tourism village criteria as a basic instrument for tourism village development (Akrida and Pujani, 2017) and the Tourism Village Guideline Book (Ministry of Tourism, 2019), so it is agreed that six aspects of assessment are 1) attractions (nature and culture), 2) accessibility, 3) amenities public facilities and tourism support, 4) institutions and society, 5) marketing strategies, and 6) industry. In addition, in this FGD, the participants also agreed on the weight of the assessment for each variable. The assessment instrument can be seen in detail in table 1.

\section{Table 1. Assessment Instruments for Tourism Villages in West Manggarai Regency}

\begin{tabular}{lll}
\hline Aspects & \multicolumn{1}{c}{ Variables } & Values \\
\hline \multirow{3}{*}{} & A. Natural Attraction & $17 \%$ \\
\cline { 2 - 3 } & Landscapes (rice terraces, plantations, valleys, waterfalls, sand dunes, springs, etc.) & $12 \%$ \\
\cline { 2 - 3 } & There are unique biological phenomena (bat caves, bird forests, etc.) & $12 \%$ \\
\cline { 2 - 3 } & There are flora / plants that are endemic and unique & $12 \%$ \\
\cline { 2 - 3 } & There are fauna / animals that are endemic and unique & $7 \%$ \\
\cline { 2 - 3 } & There is potential and opportunities for activities (trekking, rafting, snorkeling, etc.) & \\
\cline { 2 - 3 } & B. Cultural Attraction &
\end{tabular}


$\begin{array}{ll}\text { There is a traditional house (drum house) } & 4 \%\end{array}$

$\begin{array}{ll}\text { There are Natas / Playgrounds } & 3 \%\end{array}$

$\begin{array}{ll}\text { There is a Compang } & 3 \%\end{array}$

\begin{tabular}{ll}
\hline There is a Lingko & $1 \%$
\end{tabular}

$\begin{array}{ll}\text { There are historical sites } & 2 \%\end{array}$

$\begin{array}{ll}\text { There are village myths / legends } & 2 \%\end{array}$

There are unique and distinctive traditional rituals / traditional ceremonies / festivals $2 \%$

There are traditional ceremonies / cultural festivals (large scale activities) for example the penti $2 \%$ ceremony

$\begin{array}{ll}\text { There are traditional games } & 2 \%\end{array}$

$\begin{array}{ll}\text { There is a form of dance art } & 3 \%\end{array}$

There are songs and musical instruments (landu tepong) $3 \%$

$\begin{array}{ll}\text { There is a cultural center } & 3 \%\end{array}$

There are cultural figures who are still actively creating $3 \%$

$\begin{array}{ll}\text { There are market days } & 2 \%\end{array}$

The community conserves and makes use of the spring / wae barong for tourism $3 \%$

$\begin{array}{ll}\text { There is a unique culinary village } & 2 \%\end{array}$

\begin{tabular}{ll} 
National road & $6 \%$ \\
\hline Provincial road & $8 \%$
\end{tabular}

\begin{tabular}{ll} 
Provincial road & $8 \%$ \\
\hline District Street & $10 \%$
\end{tabular}

\begin{tabular}{ll} 
District Street & $10 \%$ \\
\hline Village Road & $15 \%$
\end{tabular}

\begin{tabular}{ll} 
Village Road & $15 \%$ \\
\hline Internal roads $/$ paths in the DTW & $10 \%$
\end{tabular}

\begin{tabular}{ll}
\hline Internal roads / paths in the DTW & $10 \%$ \\
\hline Public Wharf (fisher & $12 \%$
\end{tabular}

\begin{tabular}{ll}
\hline Public Wharf (fishermen / people) & $12 \%$
\end{tabular}

\begin{tabular}{ll} 
Travel dock & $13 \%$ \\
\hline
\end{tabular}

\begin{tabular}{ll}
\hline Directional signs & $8 \%$ \\
\hline Public mode of
\end{tabular}

\begin{tabular}{ll}
\hline Public mode of transportation to a tourist attraction & $10 \%$
\end{tabular}

$\begin{array}{ll}\text { Child \& disability friendly } & 8 \%\end{array}$

$\begin{array}{ll}\text { A. Public Facilities } & 3 \% \\ \text { Electricity / other sources of lighting } & 3 \%\end{array}$

\begin{tabular}{ll} 
Electricity / other sources of lighting & $3 \%$ \\
\hline Clean water & $5 \%$ \\
\hline
\end{tabular}

$\begin{array}{ll}\text { Telecommunication network } & 3 \%\end{array}$

\begin{tabular}{ll}
\hline Financial \& banking facilities & $1 \%$
\end{tabular}

$\begin{array}{ll}\text { Medical facility } & 3 \%\end{array}$

\begin{tabular}{ll} 
Availability of access to health facilities & $4 \%$ \\
\hline
\end{tabular}

\begin{tabular}{ll} 
CHSEs facilities & $1 \%$ \\
\hline Access to worship facilities & $1 \%$
\end{tabular}

\begin{tabular}{ll}
\hline Access to worship facilities & $1 \%$ \\
\hline Security facility (gardpost)
\end{tabular}

\begin{tabular}{ll} 
Security facility (guard post) & $1 \%$ \\
\hline
\end{tabular}

\begin{tabular}{ll} 
Trash can & $3 \%$ \\
\hline
\end{tabular}

$\begin{array}{ll}\text { Wastewater and drainage management } & 2 \%\end{array}$

\begin{tabular}{ll}
\hline Public toilet & $5 \%$ \\
\hline
\end{tabular}

\begin{tabular}{ll}
\hline Traditional market & $3 \%$ \\
\hline Grocery stall & $1 \%$
\end{tabular}

\begin{tabular}{ll} 
Grocery stall & $1 \%$ \\
\hline Parking area & $3 \%$
\end{tabular}

\begin{tabular}{ll}
\hline Parking area & $3 \%$ \\
\hline Community meeting hall (village hall) & $1 \%$
\end{tabular}

\begin{tabular}{ll}
\hline Community meeting hall (village hall) & $1 \%$ \\
\hline
\end{tabular}

B. Tourism Support Facilities

$\begin{array}{ll}\text { Accommodation } & 10 \%\end{array}$

\begin{tabular}{ll}
\hline eating \& drinking facilities & $7 \%$ \\
\hline
\end{tabular}

\begin{tabular}{ll} 
Gazebo & $2 \%$ \\
\hline Pergola & $2 \%$
\end{tabular}

\begin{tabular}{ll}
\hline Pergola & $2 \%$ \\
\hline Art stage & $3 \%$
\end{tabular}

\begin{tabular}{ll}
\hline Art stage & $3 \%$ \\
\hline Guardiail & $2 \%$
\end{tabular}

\begin{tabular}{ll} 
Guardrail & $2 \%$ \\
\hline Gate of identity & $5 \%$
\end{tabular}

\begin{tabular}{ll} 
Gate of identity & $5 \%$ \\
\hline
\end{tabular}

\begin{tabular}{ll} 
Souvenir shopping center & $8 \%$ \\
\hline
\end{tabular}

\begin{tabular}{ll} 
Tower of view & $1 \%$ \\
\hline Boardwalk & $1 \%$
\end{tabular}

\begin{tabular}{ll} 
Boardwalk & $1 \%$ \\
\hline
\end{tabular}

\begin{tabular}{ll}
\hline Tourist directions / information boards & $7 \%$
\end{tabular}

$\begin{array}{ll}\text { Tourist information center } & 7 \%\end{array}$ 


\begin{tabular}{|c|c|c|}
\hline & Special facilities for people with physical disabilities, children and the elderly & $3 \%$ \\
\hline & Recreational facilities (parks, benches) & $1 \%$ \\
\hline & Availability of lighting at Tourist Attractions & $1 \%$ \\
\hline \multirow{13}{*}{ 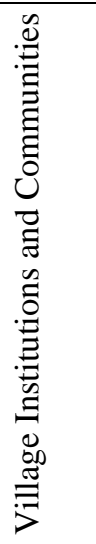 } & Village Level Tourism Awareness Group (POKDARWIS) & $15 \%$ \\
\hline & Village Owned Enterprises (BUMDes) & $10 \%$ \\
\hline & There is cooperation with other institutions & $5 \%$ \\
\hline & Strengthening human resources (training / technical guidance) & $15 \%$ \\
\hline & Tourism Communication Forum & $5 \%$ \\
\hline & Residents of tourism school graduates & $7 \%$ \\
\hline & People of productive age live in the village & $5 \%$ \\
\hline & Citizens can speak foreign languages & $8 \%$ \\
\hline & Residents work in the tourism sector & $5 \%$ \\
\hline & Active community groups (arts, studios, craftsmen, UKM, PKK) & $8 \%$ \\
\hline & Potential for conflict & $2 \%$ \\
\hline & Tourist security task force & $5 \%$ \\
\hline & Tourism-related regulations (village regulations, decrees, etc.) & $10 \%$ \\
\hline \multirow{5}{*}{ 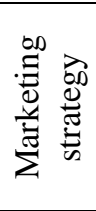 } & Have participated in an exhibition / tourism market / the like & $20 \%$ \\
\hline & Have a tourism image / branding & $20 \%$ \\
\hline & Have a marketing partnership (travel agents, tour operators, hotels, etc.) & $30 \%$ \\
\hline & Have offline promotional materials & $5 \%$ \\
\hline & Have online promotional materials & $25 \%$ \\
\hline \multirow{7}{*}{ 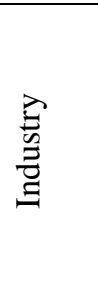 } & Professional Certification & $10 \%$ \\
\hline & Business Certification & $10 \%$ \\
\hline & Culinary Business & $20 \%$ \\
\hline & Souvenir business & $15 \%$ \\
\hline & Village tour packages & $20 \%$ \\
\hline & Tourist visits & $15 \%$ \\
\hline & Have a Standard Operating Procedure (SOP) & $10 \%$ \\
\hline
\end{tabular}

Source: Processed by researcher, 2020

The assessment of each variable uses a Likert scale of zero to three, where $0=$ nonexistent or not available, $1=$ severely damaged or not yet managed, $2=$ moderately damaged or already managed but not intended for tourism, and $3=\operatorname{good}$ condition or already managed in context tourism. The total weight of an aspect is not more than $100 \%$. This instrument is used for two purposes, namely 1) assessing the readiness of a village to be recommended as a tourism village; and 2) create a village development strategy that has been designated as a tourist village. The determination of a development strategy for a tourism village is based on an assessment of the six aspects agreed upon in the FGD. However, this research focuses on assessing the readiness of a village before it is designated as a tourism village.

In accordance with the results of the FGD, in determining the final score of the readiness of a village to become a tourism village, the most important aspects are the aspects of attraction, and institutional and community aspects. The attraction aspect itself is a potential that will be offered to visitors, and the institutional and community aspects show the readiness of the community to manage rural tourism through village community institutions. Based on the Ministry of Home Affairs Regulation number 18 of 2018 concerning Village Community Institutions and Traditional Institutions, it is explained that one of the functions of village social institutions is to participate in the planning, implementation, and supervision of village development. This is used as the basis for the Regional Government of West Manggarai Regency to determine that there are two aspects; attractions and institutions and the community are the initial components of assessing the readiness of a village to become a tourist village, so the formula used is as follows: 


$$
\text { final score }(\%)=\frac{T A(\%)+T K M(\%)}{2}
$$

Source: Processed by researcher, 2020

Where TA is the total value of the attraction variable, TKM is the total value of the institutional and community variables.

The final score will be interpreted using an interval value, where the interval value uses the formula, as follows:

$$
\begin{gathered}
N=\frac{100 \%}{L} \\
N=\frac{100 \%}{3}=33,33 \%
\end{gathered}
$$

Where $\mathrm{L}$ is the maximum score for each sub variable, namely three. The researcher determined that 1) $0 \%-33.9 \%$ means that the village cannot be recommended as a tourist village; 2) $34 \%-67.9 \%$ means that the village can be recommended as a tourist village with a record; and 3) $68 \%-100 \%$ means that the village is highly recommended as a tourist village. Thus, based on this formula, the researcher has the opinion that the final score of assessing the readiness of a village to become a tourist village can be interpreted into three categories in table 2 below.

Table 2. Village Readiness Assessment Category Results

\begin{tabular}{lll}
\hline No & Score & \multicolumn{1}{c}{ Category } \\
\hline & & $\begin{array}{l}\text { The village cannot yet be } \\
\text { recommended to become tourist } \\
1\end{array} \quad \begin{array}{l}0 \%- \\
\text { villages, because the assessment } \\
\end{array}$ \\
& & $\begin{array}{l}\text { of aspects of attractions, and the } \\
\text { community and institutions has } \\
\text { not been fulfilled. }\end{array}$ \\
\hline
\end{tabular}

\begin{tabular}{ll}
\hline & $\begin{array}{l}\text { The village can be recommended } \\
\text { to be a tourist village with a note, } \\
\text { because the assessment of the } \\
\text { aspects of the attraction, and the } \\
\text { community and institutions have } \\
\text { been fulfilled, but not maximally. } \\
\text { There needs to be an improvement } \\
\text { in this aspect. }\end{array}$ \\
\hline $367,9 \%-$ & $\begin{array}{l}\text { The village is highly } \\
\text { recommended to be a tourist } \\
\text { village, because the assessment of } \\
\text { the aspects of the attraction, and } \\
\text { the community and institutions } \\
\text { have been fulfilled properly. }\end{array}$ \\
&
\end{tabular}

Source: Processed by researcher, 2020

\section{Data Collection Process}

The data collection process was carried out on 23 to 25 november 2020 in Wae Sano village, Sano Nggoang subdistrict, and Wae Lolos village, Mbeliling sub-district through two stages, namely 1) focus group discussion (FGD), which was attended by village governments and leaders. community, and 2) field observations.

\section{RESULTS AND DISCUSSION}

There are 68 villages proposed to be tourism villages in West Manggarai Regency, two villages were used as samples for assessing the readiness of villages to become tourism villages using predetermined instruments, namely Wae Sano Village in Sano Nggoang District, and Wae Lolos Village in Mbeliling District. The results of the tourism village assessment in detail can be seen in table 2 .

Table 2 Assessment Results of Tourism Villages

\begin{tabular}{|l|c|c|c|c|c|c|}
\hline Village Name & $\begin{array}{c}\text { Total } \\
\text { Attraction } \\
\text { Score }\end{array}$ & $\begin{array}{c}\text { Total } \\
\text { Accessi- } \\
\text { bility } \\
\text { Score }\end{array}$ & $\begin{array}{c}\text { Total } \\
\text { Ame- } \\
\text { nity } \\
\text { Score }\end{array}$ & $\begin{array}{c}\text { Total } \\
\text { Institutional } \\
\text { and } \\
\text { Community } \\
\text { Score }\end{array}$ & $\begin{array}{c}\text { Total } \\
\text { Marketing } \\
\text { Strategy } \\
\text { Score }\end{array}$ & $\begin{array}{c}\text { Total } \\
\text { Indus- } \\
\text { try } \\
\text { Score }\end{array}$ \\
\hline Wae Sano & $37 \%$ & $36 \%$ & $27 \%$ & $58 \%$ & $13 \%$ & $35 \%$ \\
\hline Wae Lolos & $42 \%$ & $26 \%$ & $12 \%$ & $47 \%$ & $18 \%$ & $15 \%$ \\
\hline
\end{tabular}

Source: Processed by researcher, 2020 


\section{Wae Sano Village}

Wae Sano Village is a village located in Sano Nggoang District. The village is located on the shore of the Sano Nggoang

Volcanic Lake which is a major tourist attraction. In addition, this village also has a wealth of fauna, such as birds endemic to Flores, such as the Celepuk Flores (Otus alfredi). The people of Wae Sano Village still have the habit of making woven mats from pandanus leaves, so that they can be used as potential cultural attractions, as well as original souvenirs from Wae Sano Village. However, from an institutional perspective, this village does not yet have a BUMDes, even though there is actually a pokdarwis organization (tourism awareness group).

Based on the research instrument, Wae Sano Village obtained the following: total score of the attraction value variable $37 \%$, total accessibility - $36 \%$, the total value of amenities - $27 \%$, institutional and community - 58\%, marketing strategy $13 \%$, and industry $-35 \%$. The final score for Wae Sano Village is $48 \%$, where this score can be entered in the village category and can be recommended as a tourist village with notes.

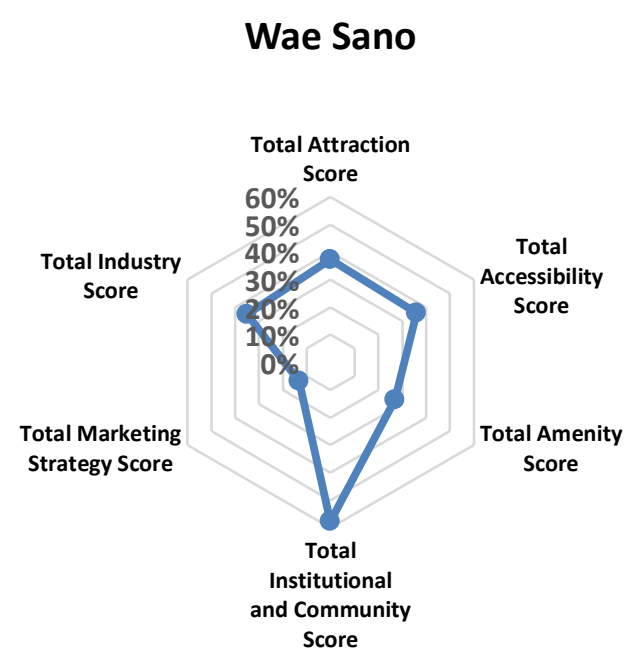

Figure 1. Results of the Wae Sano Village Assessment

Source: Processed by researcher, 2020

Based on the appraisers using research instruments, it was found that Wae Sano Village still has shortcomings in aspects of amenities and marketing strategies. Increasing amenities that can be done include making information on the DTW, increasing the village office as a tourism information center, and other tourism support facilities, while improving the aspects of the Wae Sano Village marketing strategy can collaborate with the private sector (travel agents, hotels, etc.), and make offline and online promotional materials. Details of the Wae Sano Village assessment based on all these aspects can be seen in Figure 1.

\section{Wae Lolos Village}

Wae Lolos Village is located in Sano Nggoang District. This village has potential natural attractions, including rice fields and hot springs. In addition, Wae Lolos Village also has traditional house villages that can be used as cultural attractions. From an institutional and community perspective, Wae Lolos Village already has BUMDes and POKDARWIS.

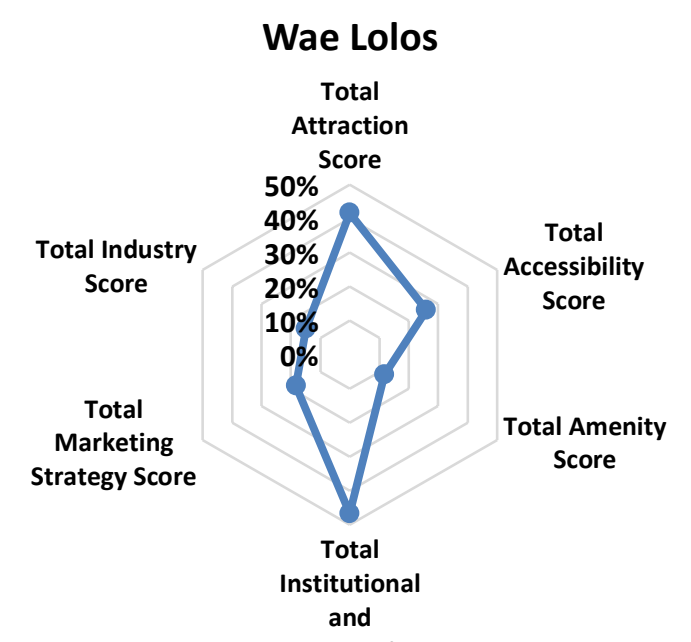

Figure 2. Results of the Wae Lolos Village Assessment

Source: Processed by researchers, 2020

Based on the research instrument, Wae Lolos Village obtained the following scores: total variable score of attraction value $42 \%$, total accessibility $-26 \%$, total amenity value - $12 \%$, institutional and community - $47 \%$, marketing strategy $-18 \%$, and industry -15 $\%$. The final score for Wae Lolos Village is $44 \%$, where this score can be entered in the 
village category and can be recommended as a tourist village with a note. These notes can be seen in the aspects of amenities, industry, and marketing strategy. In the amenity aspect, Wae Lolos Village needs to improve the amenity aspects by providing accommodation services, such as homestays, providing an information center, and other tourism support facilities. The industrial aspect in Wae Lolos Village can be improved in several ways, including conducting community training therefore, they can have certified workers and businesses in the tourism industry, and making tour packages based on village potential. Making promotional materials online and offline and being active in tourist fairs is an effort that can be done to improve aspects of the marketing strategy. Details of the Wae Lolos Village assessment based on all these aspects can be seen in Figure 2.

\section{CONCLUSIONS}

The village assessment instrument in West Manggarai Regency was agreed to consist of six aspects, namely 1) attractions (nature and culture), 2) accessibility, 3) amenities (public facilities and tourism support), 4) institutions and communities, 5) marketing strategies, and 6) industry. These aspects have a number of different variables and the weighting of each variable is also different.

Based on the results of the assessment with these instruments, it can be concluded that Wae Sano Village is included in the village category and can be recommended as a tourist village with notes. This note is closely related to the aspects of amenities and marketing strategies, which need attention so that tourism in Wae Sano Village can develop.

Wae Lolos Village can be included in the village category and can be recommended as a tourist village with a note. The des aini note relates to aspects of amenities, industry, and marketing strategies which need attention so that tourism in Wae Sano Village can develop.
The village assessment instrument can also be used as a basis for evaluating tourism villages that are already running in West Manggarai Regency, so that based on the results of the evaluation, a tourism village development strategy can be determined.

The study of tourism villages in each region has the possibility of different variables that can be adjusted to the geographical conditions of the area, so that the assessment is in accordance with the conditions of the villages in other studies.

\section{ACKNOWLEDGMENTS}

For the smooth running of this research activity, the authors would like to thank the West Manggarai Regency Research and Development Planning Agency, West Manggarai Regency Tourism and Culture Office, the Community and Village Empowerment Service, Swisscontact SUSTOUR, Wae Sano Village Heads and Wae Lolos.

\section{REFERENCES}

Akrida, I. N. S. \& Punjani, L. P. K. (2017). Kajian Penyusunan Kriteria-Kriteria Desa Wisata Sebagai Instrumen Dasar Pengembangan Desa Wisata. Jurnal Analisis Pariwisata. 17(1).

Amerta, I. M. S. (2017). The role of tourism stakeholders at Jasri tourism village development, Karangasem regency. International Journal of Social Sciences and Humanities (IJSSH), 1(2), 20-28.

Ayazlar, G. \& Ayazlar R. A. (2015). Rural Tourism: A Conceptual Approach. Tourism, Environment and Sustainability. Sofia: St. Kliment Ohridski University Press

Badan Pusat Statistik. (2018). Jumlah Devisa Sektor Pariwisata (Miliar US \$), 2016-2018

Hadiwijoyo, S.S. (2012.). Perencanaan pariwisata perdesaan berbasis masyarakat: (sebuah pendekatan konsep). Yogyakarta: Graha Ilmu. 
Kementerian Pariwisata. (2019). Buku Pedoman Desa Wisata. Edisi I.

Khandare, V., \& Phophueksanand, N. (2018). Social and Cultural Impact of Tourism Development in Thailand. International Journal of Research in Economics and Social Sciences, 8(2), 877-887.

Leonandri, D., \& Rosmadi, M. L. N. (2018). The role of tourism village to increase local community income. Budapest International Research and Critics Institute (BIRCI-Journal): Humanities and Social Sciences, 1(4), 188-193.

Nuryanti, W. (1993). Concept, Perspective and Challenges. Makalah bagian dari Laporan Konferensi Internasional mengenai Pariwisata Budaya. Yogyakarta: Gadjah Mada University Press.

Peraturan Menteri Dalam Negeri Nomor 18 Tahun 2018. Lembaga Kemasyarakatan dan Lembaga Adat Desa. 9 April 2018. Berita Negara Republik Indonesia Tahun 2018 Nomor 569. Jakarta.

Peraturan Menteri Kebudayaan dan Pariwisata Nomor KM.18/HM.001/MKP/2011.

Pedemoman Umum Program Nasional Pemberdayaan Masyarakat (PNPM) Mandiri Pariwisata Melalui Desa Wisata. 13 Maret 2012. Berita Negara Republik Indonesia Tahun 2012 Nomor 197. Jakarta.

Pusparani, Y. (2019). Perencanaan Destination Branding Melalui Mural di Desa Wisata, Desa Sumber Harapan, Kalimantan Barat. In Sandyakala: Prosiding Seminar Nasional Seni, Kriya, dan Desain. (Vol. 1, pp. 353363).

Franisal, P. N. (2020). Analysis of Homestay Criteria Compliance in Tourist Village According to the Visitor's Perception. TRJ Tourism Research Journal, 4(2), 133-149.

Gundolf, K., \& Jaouen, A. (2005). Patterns and coordination of collective action in small and very small business: the case of a tourist village in the Pyrenees. International Journal of Entrepreneurship and Small Business, 2(4), 392-403.

Hidayatullah, S., Rachmawati, I. K., Khouroh, U., \& Windhyastiti, I. (2017, August). The Effectivity of "Pokdarwis" Role on Successfully Marketing of Tourism Village Towards "Mega Tourism: Batu City For The World". In International Conferences SDGs 2030 Challenges and Solutions (Vol. 1, No. 1).

Komariah, N., Saepudin, E., \& Rodiah, S. (2018). Development of tourist village based on local wisdom. Journal of Environmental Management \& Tourism, 9(6 (30)), 1172-1177.

Muganda, M., Sirima, A., \& Ezra, P. M. (2013). The role of local communities in tourism development: Grassroots perspectives from Tanzania. Journal of Human Ecology, 41(1), 53-66.

Sharafieva, D. R. (2012). Funktsii turizma v sotsialno ekonomicheskoy structure obschestva. Известия Казанского государственного архитектурностроительного университета, (4 (22)), 78-86.

Telfer, D. \& R. Sharpley. (2008). Tourism and Development in the Developing World. London: Routledge.

United Nations World Tourism Organization. Rural And Mountain Tourism. Diunduh pada 10 desember 2020 dari https://www.unwto.org/ruralmountain-tourism.

Williams, C. (2007). Research Methods. Journal of Business \& Economic Research. 5(3).

World Travel \& Tourism Council. (2020). Travel \& Tourism: Global Economic Impact \& Trends 2020.

Yoeti, Oka. (1996). Pengantar Ilmu Pariwisata. Bandung: Angkasa. 
84 - JITHOR Vol.4, No.8, April 2021 - eISSN : 2654-4687 pISSN : 2654-3894 